\title{
The Infographic Model of Design Thinking Process $\begin{gathered}\text { Pelin Kockan Özyldiz } \\ \text { Pelin Ylddiz" }\end{gathered}$
}

\begin{abstract}
Purpose

Creativity as an outcome of our thoughts and actions is a controversial concept that has been discussed by many disciplines in different ways. In the light of cognitive research on creativity, this study aims to deal with the components of the idea generation process specific to interior design education. Based on the study conducted in the interior design studio, this paper introduces the infographic model of design thinking. the main purpose of the model is to summarize how design students initiate the design process, create their own design ideas, and also how they lead design thinking for a spatial solution.

\section{Design/Methodology/Approach}

The cross-disciplinary research paper within the context of the psychological studies on creative cognition consists of a detailed analysis of the design process in the design studio. A case study was conducted in the second-year undergraduate interior design studio at Hacettepe University in order to observe the students' experiences during one semester. In the wake of this qualitative research, the data obtained from 15 design students selected have been analyzed gradually and a design thinking model has been generated with the findings.
\end{abstract}

Keywords: Creativity, creativity models, design thinking process, design education, interior design studio.

${ }^{*}$ Res. Asst., Department of Interior Architecture and Environment Design, Faculty of Fine Arts, Hacettepe University, Ankara, Turkey.

Email: pelinkockan@hacettepe.edu.tr ORCID No: https://orcid.org/00000001-8598-9425

${ }^{* *}$ Prof., Department of Interior Architecture and Environment Design, Faculty of Fine Arts, Hacettepe University, Ankara, Turkey. Email: peliny@hacettepe.edu.tr ORCID No: https://orcid.org/00000002-7201-8213 


\section{Findings}

In addition to the interpretation of the creativity models from the literature, initial analyses showed that design thinking can be explained in three main stages as preparation, conceptualization, and spatialization that underlie the internal and external process of design thinking in the design studio. With subsequent analyses, these stages have been divided into different strategical layers according to students' experiences. As a result, the infographic model of the design thinking process is structured based on the evaluations of these components and the design approaches identified.

\section{Research Limitations/Implications}

The data acquired from the case study undertaken by the author were compared so as to identify the similarities and diversities of these processes. More research on different stages of the design process can shed more light on design thinking. In addition to this, qualitative data are based on a small group of students to get detailed information about the process. The proposed model can be adapted for different studies in the context of the design studio with more participants.

\section{Practical/Social Implications}

The proposed model in the research is intended to be used as a content map that shows the alternative ways of thinking in design ideation, and also an analysis method of the design process for future studies. In other words, the paper shows the two-way implications of the design thinking model on design education. One of which is a guide for practical use for design students and the other is an analytical tool for studio instructors or researchers.

\section{Originality/Value}

This study brings to focus on conceptualization and spatialization for creative idea generation in design studio education. On the basis of drawn from creativity models, the paper introduces a new process model that provides an original interpretation of existing models in design. The proposed model differs from previous cognitive studies, as it expands the ideation process with both internal and external operations.

\section{INTRODUCTION}

Creativity refers to the transformation of the existing things into new things through a unique, original manner. In addition to its perception as innate talent or gift, creativity exists in everyone at different levels, when considered as an act of generating ideas in a new way. Many theoretical studies have measured this talent and attempted to improve creative potential by examining the mental mechanisms of creative thinking. Especially with cognitive research, the nature of creative thinking and the components of the idea generation processes have been defined as multifaceted. These cognitive studies about creative idea generation, the basis of design, have gained significance and supported design education in different aspects. 
In this study, which inquires idea generation in design, creative processes have been identified through the stages of association, interpretation, and transformation. Accordingly, it is aimed to analyze the components of these stages and to discover different tendencies in the design studio.

To that end, in this research, cognitive approaches explaining the concept of creativity have been discussed and previously produced creativity models have been presented. Following, the effects of these studies on design practice and design pedagogy have been analyzed, and cognitive models, developed for design education, have been scrutinized. Finally, along with all the data obtained from the case study conducted in the design studio, the multilayered thinking structure of the designer has been represented by the infographic model of the design thinking process.

\section{CREATIVITY}

Creative production, which lies behind scientific, artistic and technological developments, exists at the intersection of many disciplines. Due to this reason, there are many explanations based on different paradigms related to creativity. Chronologically, the concept of creativity could not be described scientifically before the 1960 s, whereas studies on creativity increased in number in the 1960s when the structure of the human mind began to be construed. These studies demonstrated that creativity is an act of mental production essentially, and therefore, it was acknowledged that it exists in every mind to some extent (Lowenfeld, 1947; Rouquette, 1992; Smith et al., 1995).

The objective measurement of creative potential became possible through creativity tests. In order to improve creative performance, it became necessary to explain the structure of the human mind and to identify the factors which affect it. Therefore, many qualitative studies have been conducted on the factors affecting creativity, in addition to studies based on quantitative measurements (Getzels and Jakson, 1962; Guilford, 1968; Torrance, 1972). Among these, cognitive studies based on thinking, information processing, and problem-solving skills, set light to the mental processes that lie behind creativity (Finke et al., 1992; Cross, 2001; Runco, 2007; Ward, 2007). Based on these explanations, especially cognitive approaches, that deal with the mental processes of creativity, have gained importance for this study. 


\section{CREATIVE COGNITION}

Cognition refers to mental operations such as perception, conceptualization, knowing, learning, and problem-solving. Cognitive approaches attempt to explain creativity through the mental representations of these processes. There are two main concepts for creativity within the scope of cognitive studies. The first one is cognitive processes that describe the mental mechanisms and the second one is cognitive styles that represent the individual approaches or preferences during these processes (Fakhra, 2012).

Martinsen, Kaufmann, and Furnham (2011; 214) define the concept of style as the "preferred manner or way of doing things" and interpret the cognitive style as "individual differences in the ways people organize and process information". According to this, even though cognitive processes are the same for everyone, it can be said that different approaches and behavior patterns in the process vary due to cognitive styles. It was observed that cognitive styles such as thinking visually or verbally, analytical or holistic organization of information indicate an opposite bipolar tendency. In contrast, more tendencies were discovered in some research (Martinsen et al., 2011; 215). Even though cognitive styles are perceived as a measurement for creativity, studies on education, in particular, showed that both tendencies may be advantageous at different stages of creative thinking (Cross, 2001; Demirbaş, 2001; Fakhra, 2012). In this regard, styles have not been enough on their own to explain the structure of creative thinking, and therefore the knowledge of cognitive processes has become a necessity.

The cognitive processes of creativity are generally associated with problem-solving (Guilford, 1968; Newell and Simon, 1972; Schön, 1985) or problem finding activities (Cross, 2001, Benami, 2002; Runco, 2007). Runco (2007; 16) expands the scope of problem finding in a cognitive sense as "problem construction, problem identification, problem definition, problem discovery, problem perception, and problem generation". According to this, it can be said that what matters for creativity is not only the solution but also the formulation of the problem.

The meaning of the term "problem" varies depending on the creative production field. For instance, Runco associates the problem in an artistic production with the artist's conceptual or formal search. He defines the "problem finding" as "problem expression" and states that the "problem is not extrinsic, but more a matter of finding a way to capture a feeling or need" (Runco, 2007; 17). It can be said that this explanation also applies to design disciplines at the intersection of science and art. A design problem generally includes more than the 
requirements and is most of the time defined through the designer's insights.

Another issue as important as a problem in cognitive researches is knowledge because configuration or formulation of the problem is directly associated with the relevant information about it. In creative thinking, various information related to the problem comes together and forms ideas. By changing these pieces of information, a new problem and accordingly a new knowledge can be generated. In other words, the problem and knowledge fields are in a dynamic relationship through bidirectional communication (Kahvecioğlu, 2001).

In any act of production, stored memories and knowledge in mind regarding concepts, objects, and events, associates with newly acquired information and generates new syntheses through several networks (Ward, 2007). Generating an idea out of the existing information stands for an association that takes place in mind beyond control. This has been explained through Mednick's associative theory. This theory holds that information and experiences generate ideas by coming together in mind through free associations (Mednick 1962; Andreasen, 2011). There is such a link behind the novelty and originality value of creative production. However, Runco $(2012 ; 602)$ drew attention to the importance of establishing this connection with the right relationships and identified two important requirements for a creative idea: "originality" and "effectiveness".

In the generation of creative ideas, analogy and metaphor are among the frequently employed methods for new syntheses (Runco, 2007). Analogy stands for semantic or formal references between two similar things, whereas metaphor represents the figurative use of similarities in differences. In both of these methods, the main point is the transition of similarities or affinities. However, the similarity between these things runs the risk of extreme adhesion to the origin or getting out of the scope. Therefore, interpretation and transformation of the origin are the most important operations in analogy and metaphor. Thus, creativity ceases to be an uncontrolled action and turns into a conscious process of discovery.

As can be seen, the description of the problem, acquisition of relevant information, generation of new ideas, and elimination of them are discussed for a creative thinking process. In cognitive studies, these processes and their links with each other are expressed by relationship charts which have been named as creativity models. Charts can also be diversified in every model according to the emphasized content of them such as cognitive processes or styles. Therefore, a model, which explains the relationships that the researcher has focused on, should not be considered as a rule, but as a content summary. 


\section{Cognitive Models of Creativity}

The former models related to creativity have been named stage models, which attempt at explaining the mental processes with successive operations. As the creative process depends on generating plenty of ideas at first and then evaluating them, different models represent the stages with similar explanations. In his renowned model, Wallas $(1926 ; 10)$ describes the stages of creativity as "preparation, incubation, illumination and verification". The preparation stage stands for cognitive processes taking place during problem defining and information gathering. The incubation stage signifies the connecting of ideas unconsciously while retreating from the problem. In the illumination stage, associated ideas emerge suddenly, whereas in the verification stage appropriate solutions are determined. Many subsequent studies have tried to explain these stages which were described as unconscious before in more detail through problem defining, information processing, and decisionmaking, (Weisberg, 1986; Runco, 2007; Fakhra, 2012).

In the widely adopted Geneplore model, Finke, Ward, and Smith (1992; 191) suggest two main stages, "generation" and "exploration", which lead to the creative idea (Figure 1). According to the model, the process, starts with the generation of "pre-inventive structures" through "knowledge retrieval, idea association, mental synthesis, mental transformation, analogical transfer, categorical reduction, etc.", and is developed through "interpretation, hypothesis testing, attribute finding, functional inference, contextual shifting, searching for limitation, etc." (Finke et al., 1992; 192).

Figure 1. The basic structure of Geneplore Model (adapted from Finke, Ward, and Smith, 1992; 193).

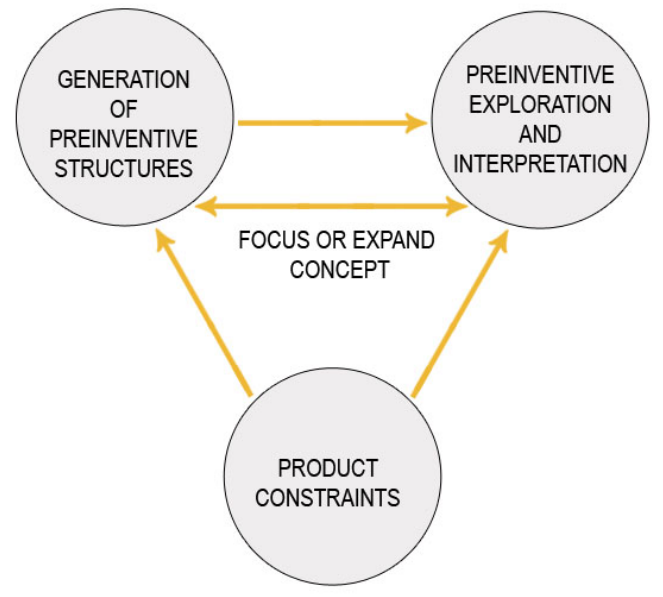

Mumford $(2017 ; 318)$, on the other hand, examines the stages of creative thinking through the processes of "problem definition, information gathering, concept/case selection, conceptual combination, idea generation, idea evaluation, implementation 
planning, adaptive execution" (Figure 2). The stage of "conceptual combination", in which different information and concepts combine to generate a new conceptual idea, has particular importance for obtaining original results.

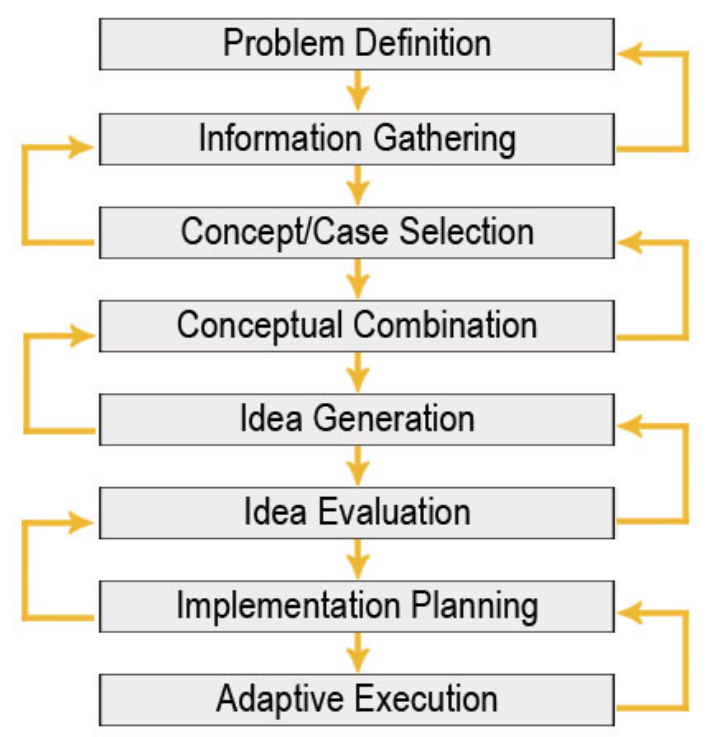

In addition to process models, componential models underline the different paradigms of creativity. For instance, in the 4P model of Rhode (1961), person, product, and press were taken into consideration besides the process. Runco and Chand (1995) proposed the two-tier model of creativity. In the first layer of the model, they explain "problem finding, idea generation, and evaluation" processes, whereas they address "motivation" involving internal and external factors affecting the process, and "knowledge" in the second layer (Figure 3).

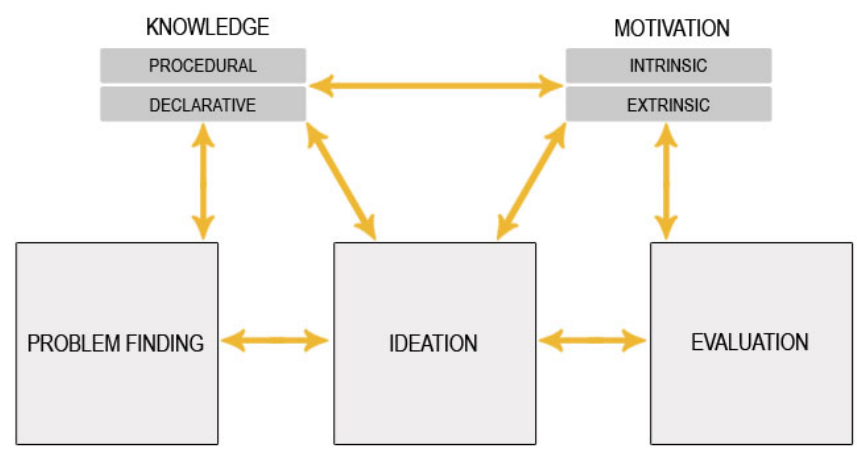

As can be seen, some of the models focus on the process, whereas some others explain creativity through cognitive styles, strategies, or factors, etc., in a multi-dimensional manner. The
Figure 2. Creative process model (adapted from Mumford, 2017; 318).

Figure 3. Two-tier model of creative thinking (adapted from Runco and Chand, 1995; 245). 
basic cognitive mechanisms of creativity such as informationprocessing or problem-finding explained through the models above, have been contributed to this research in order to define creative thinking within the scope of interior design.

\section{DESIGN COGNITION}

Design, expanding between art and science, is one of the outstanding disciplines influenced by creativity research in cognitive psychology. Cognitive approaches have discussed processes of creativity, such as problem-solving, generation of the design knowledge, and decision-making, in addition to the frame of mind behind them. The frame of the designer's mind and thinking processes are known as design cognition.

What differentiates design from a creative act is how the problem is formulated, how the design objectives are generated and what kind of strategies are preferred in this process. Due to the fact that the design problem is ill-defined, objectives are restructured in the course of the process. Re-defining the problem with a new target is particularly important for the designer, as it provides an opportunity to be unique. Because it is opened to external influence, there is a strong connection between creativity and the generation process. It is a dynamic process, with the potential to retrieve, open to new information or other factors at any time. In this regard, the design process should be regarded as an ongoing process of idea generation, not solely as a problem-solving operation.

\section{Cognitive Studies and Models in Design Education}

As is known, the ability of designerly thinking could be developed due to experiential knowledge gained in the studio, which lies at the center of design education. This type of knowledge includes the explicit knowledge of design called "declarative" and the methodological knowledge of design called "procedural" (Uluoğlu, 1988; 21). The primary objective of design education is, therefore, the acquisition of these abilities about thinking and also expressing.

In this context, cognitive studies have been very important in design education. Many cognitive models were borrowed from psychology to be used in design education, and these shed light on different aspects of education. The relationship between cognitive styles and learning (Demirbaş and Demirkan, 2003; Kwan and Yunyan, 2005; Robert, 2006; Salama and Wilkinson, 2007), the meaning of designerly thinking (Lawson, 2005; Ochsner, 2000), problem-solving approaches (Cross, 2001), information, representation, and decision-making processes (Akın, 1978; Goldschmidt, 2005) are some of the outstanding exemplary studies in design education. 
Lawson in his book, How Designers Think, analyzes the designerly thinking from different aspects and presents some cognitive models (2005). In this study, he refers to the stage models as the "route maps of the design process" but also emphasizes that these consecutive maps cannot completely explain the complex structure of design thinking. Based on this, he interpreted the design process (Figure 4) as "negotiation between problem and solution through the three activities of analysis, synthesis, and evaluation" (Lawson, 2005; 48).

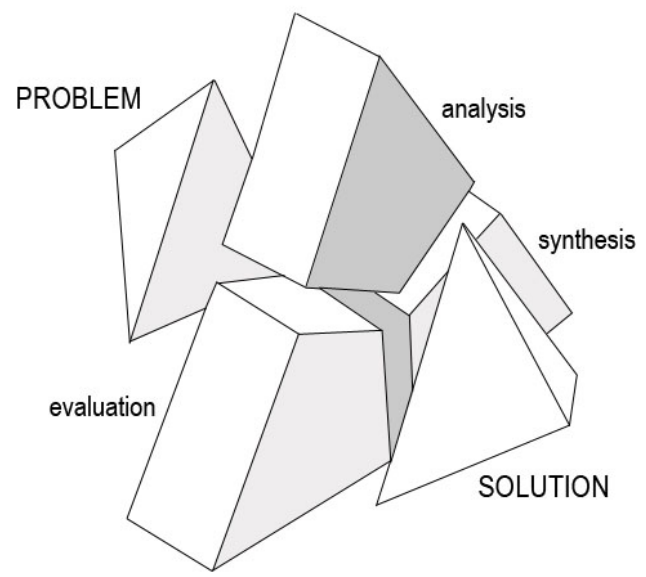

In another study, Roberts (2006) associates cognitive styles with design processes and identifies important stages in which students' cognitive styles are efficient. Ochsner (2000), who draws attention to the similarity between the process in the design studio and the psychoanalytical processes, approaches the design education from a pedagogical perspective and focuses on the individual processes of creativity in the studio.

In addition to design knowledge and design thinking, the representation of the design process is another important aspect in design education. In some cognitive studies, visual representations are evaluated as a separate stage of the process (Akın, 1978; French, 1985). Instead of this, Goldschmidt (1994) and Oxman $(1997,2004)$ describe sketches or any visual representations in visual thinking, as important tools supportive of cognitive processes.

Regarding these studies, in some of the current studies, the stages of the design process are detailed, while in others, new synthesis has been introduced. For example, Türkyılmaz and Polatoğlu $(2012 ; 103)$ determined the selection of information and its transformation, as two important creative stages in the "early design phase".

Fakhra (2012), on the other hand, aims at developing the conceptual model of creativity and proposed the Meta-Creativity Componential Model, which contains the synthesis of previous
Figure 4: Lawson's map of the design process (adapted from Lawson,2005; 48). 
Four-staged model (Wallas,1926), Investment theory (Sternberg and Lubart, 1992), Geneplore Model (Finke et l.,1992), and Five characteristics of the design process (Ziesel, 2006).

Figure 5: Meta-Creativity Componential Model (adapted from Fakhra, 2012; 75). models ${ }^{1}$. He puts the "conceptual processing space" at the center, considers other components as influential factors and conditions which have an effect on the process and inspirational idea stimuli (Figure 5).

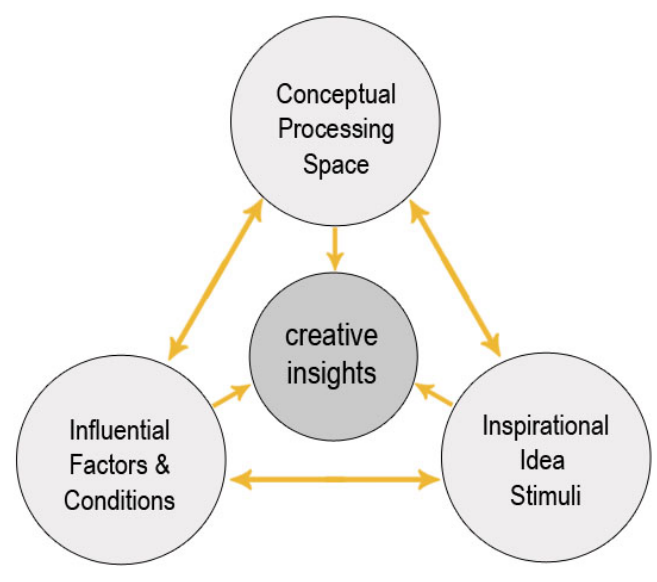

Based on the explanations above, generating a design thinking model is the purpose of this study conducted in the studio. In this study, the creative process was harmonized with the generation of design thinking and the process was structured based on the processes followed in the studio.

All the externalized information serves as valuable expressions that provide insight into the designer's thinking process. Therefore, in this study, sketches, drawing, and other visual representations are accepted as the designer's most significant tools to generate and to express ideas. The components of the design thinking process and various approaches in the process were determined through these representations generated in this study.

\section{THE STUDY}

Design thinking stands for the cognitive, practical and strategical processes through which the design concepts are developed. Based on this, a model has been built around the design process and design approaches followed in the $2^{\text {nd-year interior design }}$ studio. A design project was investigated as a case study within the scope of a doctor of fine arts research. The stages of the creative process have been determined through the contribution of the creative models from the literature. The components of these stages and different design approaches have been structured through a qualitative analysis of the data collected in the design studio. Based on the findings, the content of the study has been expanded and the design thinking model for the design studio has been developed with this research. 


\section{METHODOLOGY}

The study was conducted in the design studio with 60 students, which continued during one semester. Their experiences during the design process were evaluated through qualitative analysis. The design topic was given as a "hostel." The structural system of the building and the site on which it is located are determined as design constraints. As can be seen in the weekly chart (Figure 6), the design process began with research and then continued with conceptual design, the development of design ideas, and technical drawings.
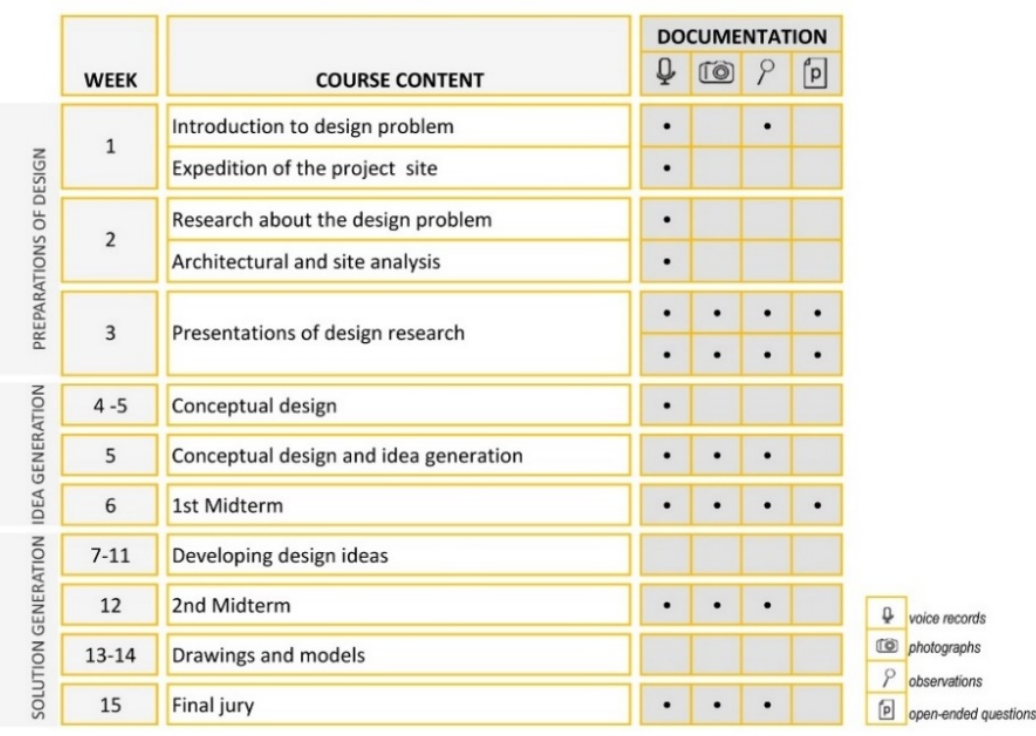

To facilitate the retrospective evaluation, visual representations, recordings, observations throughout the process and openended questions posed to the students were used as documentation methods. After the problem was given, students had to explore the design problem field from different aspects during the first three weeks. That was an important research process to be generating or defining a unique problem for them. After this preparation process, they presented initial design concepts about their design problem. For this reason, the first six weeks of the course in which original design ideas were generated explicitly, were critical for this study.A total of 2250 photographs of the design project outputs (sketches, drawings, and models) were taken, and 39 hours of presentations were recorded during the studio critiques. 19 hours of these records, including presentations of design research, conceptual design, idea generation phase, and midterms, have been completely decoded. Visual presentations of designers directly representing the design process have been selected and combined with records. After these raw data have been grouped according to the students, datasheets that document the development of the
Figure 6. Course Outline and Documentation Methods. 
participants have been prepared by the researcher. Details of these datasheets having student codes, images selected from the presentations, and information summarized from the data acquired are presented in Figure 7. The 3-piece datasheet, comprises conceptualization, form generation, and spatialization phases in order to have a holistic view of the process.

Figure 7. Explanation of data sheets

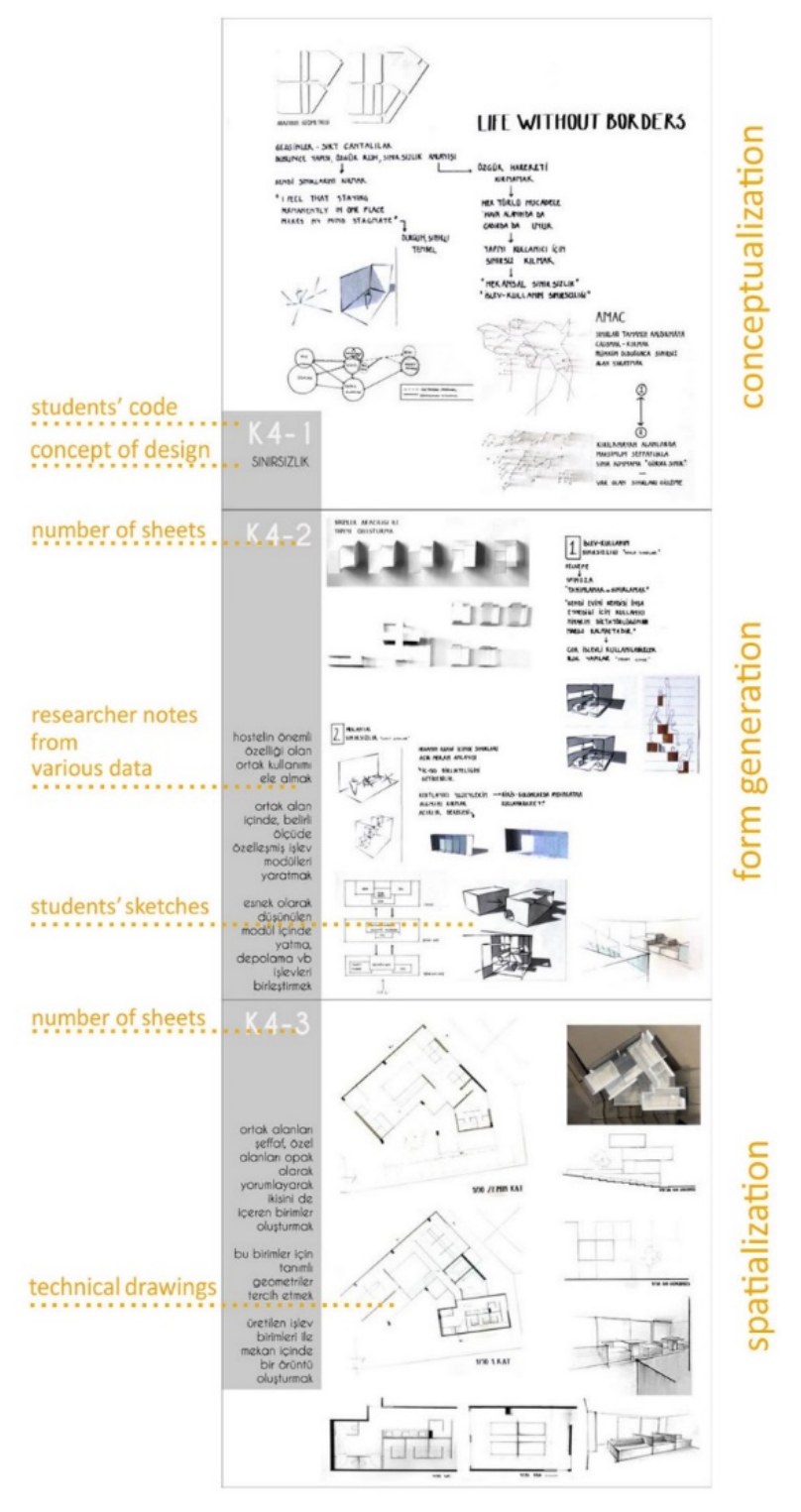

\section{DATA ANALYSIS}

Evaluation of the data acquired in the case study was realized in three stages:

- In the first stage, design thinking process models related to the scope of the study were selected from the literature, and the main stages of the design thinking process were determined by overlapping the design process followed in the studio.

-In the second stage, 15 students out of 60 , who fully participated in the course during the first three weeks, were chosen and data were deepened through their studio outputs. In this way, the 
sub-components of the process and different approaches were identified from the data acquired.

- In the third stage, the design project outputs of the remaining 45 students was checked for other approaches, and differences were added to the content.

In the evaluation of the data, the design process was analyzed by decomposing it into stages from the general to the specific. Although the design students seem to have followed a similar process, significant differences were identified in detail, therefore, the findings were expanded by deepening the data.

The success rates were avoided on purpose in the evaluation. The objective was more to see the diversity of ways in generating design ideas on the same topic. For this reason, each approach was considered as a sample for a separate classification. Every difference detected in design thinking was taken into account in determining potential ways for the designer. The aim of the model produced was to show all these possibilities simultaneously.

\section{Description of the Design Thinking Process}

In order to determine the design thinking process, stage models dealing with the creative process through cognitive operations such as problem-solving, information processing, decisionmaking and so on, were considered in the research. The stages of the models were codified depending on the processes in Figure 8 to see the relationships between them. The figure shows that the creativity process starts with the preparation stage, then, ideas come together consciously or unconsciously for an ideal solution and the solution is evaluated before application.

In this study, which focuses on the generation of design thinking in the studio, evaluation and application were excluded and other stages were adapted to the course outline. In this regard, the design thinking about a specific topic was divided into two main processes. These processes were named as the pre-design phase during which intellectual preparation related to the topic was made, and the ideation phase during which ideas were generated and became concrete.

In the pre-design phase during which the contact with the design problem increases, the aim is to reveal the information about the problem. There is an initiating step in the transition to the ideation phase, in which concepts, images or ideas are encountered. Essential information from different sources come together at this step and spread out into new alternative solutions from there. This preliminary thinking phase has been emphasized in the study, as it reveals the main idea of the design. The design solution generating stage was defined through the association of mental and formal interpretation processes which 
depend on visual thinking and visual representation as part of the necessity of studio education.

\begin{tabular}{|c|c|c|c|c|c|c|}
\hline 1970 & 1985 & 1992 & 1995 & 2001 & 2003 & \\
\hline WALLAS & FRENCH & $\begin{array}{l}\text { FINKE } \\
\text { et al. }\end{array}$ & $\begin{array}{l}\text { RUNCO } \\
\text { CHAND }\end{array}$ & CROSS & MUMFORD & \\
\hline preparation & $\begin{array}{l}\text { analysis } \\
\text { of the } \\
\text { problem }\end{array}$ & & $\begin{array}{l}\text { problem } \\
\text { finding }\end{array}$ & problem & $\begin{array}{l}\text { problem } \\
\text { finding } \\
\text { information } \\
\text { gathering } \\
\text { information } \\
\text { organization }\end{array}$ & PREPARATION \\
\hline incubation & $\begin{array}{c}\text { conceptual } \\
\text { design }\end{array}$ & $\begin{array}{l}\text { analogic } \\
\text { transfer } \\
\text { association } \\
\text { retrieval } \\
\text { synthesis }\end{array}$ & idea & (2) & $\begin{array}{l}\text { conceptual } \\
\text { combinations }\end{array}$ & $\begin{array}{l}\text { IDEA } \\
\text { GENERATION }\end{array}$ \\
\hline illumination & $\begin{array}{c}\text { embodiment } \\
\text { of } \\
\text { schemes }\end{array}$ & $\begin{array}{l}\text { contextual } \\
\text { shifting } \\
\text { functional } \\
\text { inference } \\
\text { hypothesis } \\
\text { testing }\end{array}$ & generation & generation & $\begin{array}{l}\text { Idea } \\
\text { generation }\end{array}$ & $\begin{array}{l}\text { SOLUTION } \\
\text { GENERATION }\end{array}$ \\
\hline verification & & & evaluation & & $\begin{array}{c}\text { idea } \\
\text { evaluation }\end{array}$ & EVALUATION \\
\hline & detailing & & & & $\begin{array}{l}\text { planning } \\
\text { the } \\
\text { application }\end{array}$ & APPLICATION \\
\hline
\end{tabular}

Figure 9. Outline of the design thinking process
For this reason, this cognition-based research expands the creativity process, in a way that includes internal and external processes together as outlined in Figure 9. In this respect, the study differs from others.

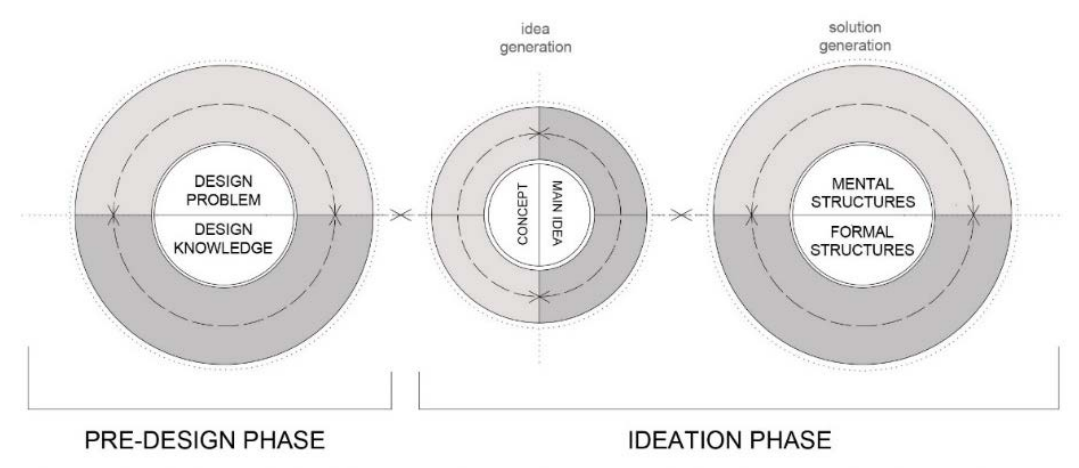

\section{Determination of Components and Approaches}

In order to see the components of the two phases stated above, in-depth analyses were made on the design project outputs of the selected 15 students. Since the traceability of these phases is varied, evaluations were made by using different methods. The 
components of the pre-design phase were determined through the content analyses of the open-ended questions (Table 1), whereas the components of the ideation phase were determined through the students' presentations, voice recordings made during critique sessions, and observations of the researcher made in studio during the design process.

Table 1. Example of content analysis in pre-design phase

\begin{tabular}{|c|c|c|c|}
\hline CODES & $\begin{array}{l}\text { ANSWERS OF } \\
\text { PARTICIPANTS }\end{array}$ & $\begin{array}{l}\text { PRIMARY } \\
\text { CATEGORIES }\end{array}$ & $\begin{array}{l}\text { SECONDARY } \\
\text { CATEGORIES }\end{array}$ \\
\hline K1. & $\begin{array}{l}\text { Social area, } \\
\text { Friendly } \\
\text { accommodation, } \\
\text { Sharing rooms. }\end{array}$ & & \\
\hline K2. & $\begin{array}{l}\text { Affordable, } \\
\text { Cultural interaction, } \\
\text { Common kitchen. } \\
\text { Public spaces, }\end{array}$ & Type of Space & \\
\hline
\end{tabular}

K3. Sharing rooms

Environmental Functional Program

factors,

K4. Cultural coexistence,
Comfort.
Affordable, Architectural

K5. Socialization, Factors

Culture change.

Comfortable,

K6. Free,

Low budget.

Limited spaces,

K7. Common areas,

Low budget.

Privacy necessity, Environmental

K8. Sharing living spaces,

Motivating sociality,

Intercultural diversity,

K9. Sincerity,

Low budget.

Traveling users,

K10. Meeting new people, User diversity.

Sociability,

Factors

Structural System

Objective

Aspects

K11. Free and limitless, Sharing living.

User diversity,

K12. Daylighting,

Neighborhood,

Low costs,

K13. Common areas,

An intimate

atmosphere.

Common spaced,

K14. Cheap

accommodation,

Accessibility.

Socialization,

Field conditions

Typology of

Architecture

Subjective

Aspects

Daylighting

Cheap

accommodation,

Touristic location.

All the data from 15 students were evaluated simultaneously in order to determine the variety of approaches in thinking 
processes. Then, the missing parameters were added to the components upon checking classwide. The components and approaches in the design process were compiled by the analysis charts as in the example in Figure 10 and then summarized with graphics that form the proposed model in the following sections.

Figure 10. Examples of analysis charts

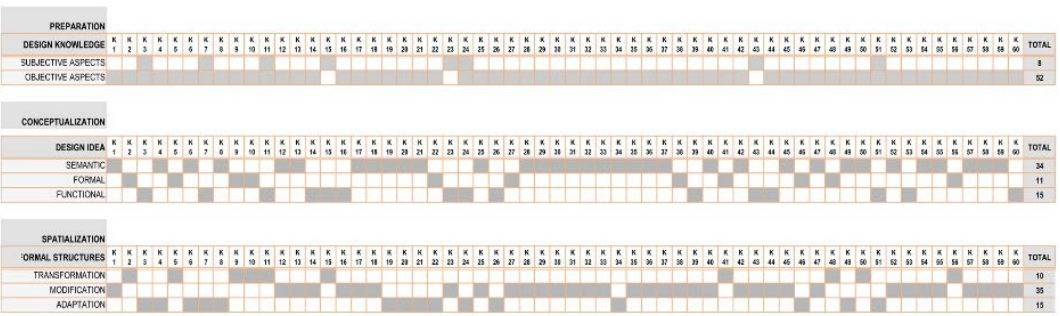

\section{Pre-Design Phase of The Design Thinking Process}

Designing means to generate an ideal solution in the face of a problem. In the design studio, an intensive research process begins to collect data on ill-defined design problems by students. The essential information integrity, which starts and leads the design, is generated from these data. Based on this, the predesign phase has been identified with two components, design problem and design knowledge, and detailed evaluations of these components have been made as follows:

- A problem in the field of design does not always indicate a troublesome situation, except for its widespread use, but rather refers to the design subject or content. By identifying the limitations and necessities related to the problem, it is expected that the designer's connotations, experiences, tendencies, and similar conscious or unconscious intuitions will interact with the problem. Analyses have shown that designers put forward some other limitations out of the given problem, utilizing their past experiences or information acquired. For instance, qualities of the "hostel" such as being "comfortable", "free", or "dynamic" have become the limitations the designers have propounded although they do not exist in the problem definition. In other words, the designer has re-defined the design problem through his/her objectives and wishes. In this light, some of the students only dealt with the defined problem, whereas some came up with a new one. This situation has been associated with the cognitive style of the designer, which is problem or solution-oriented. Also, the design problem as the first layer of the pre-design phase was detailed with the designer-dependent problems and designer-independent problems. 


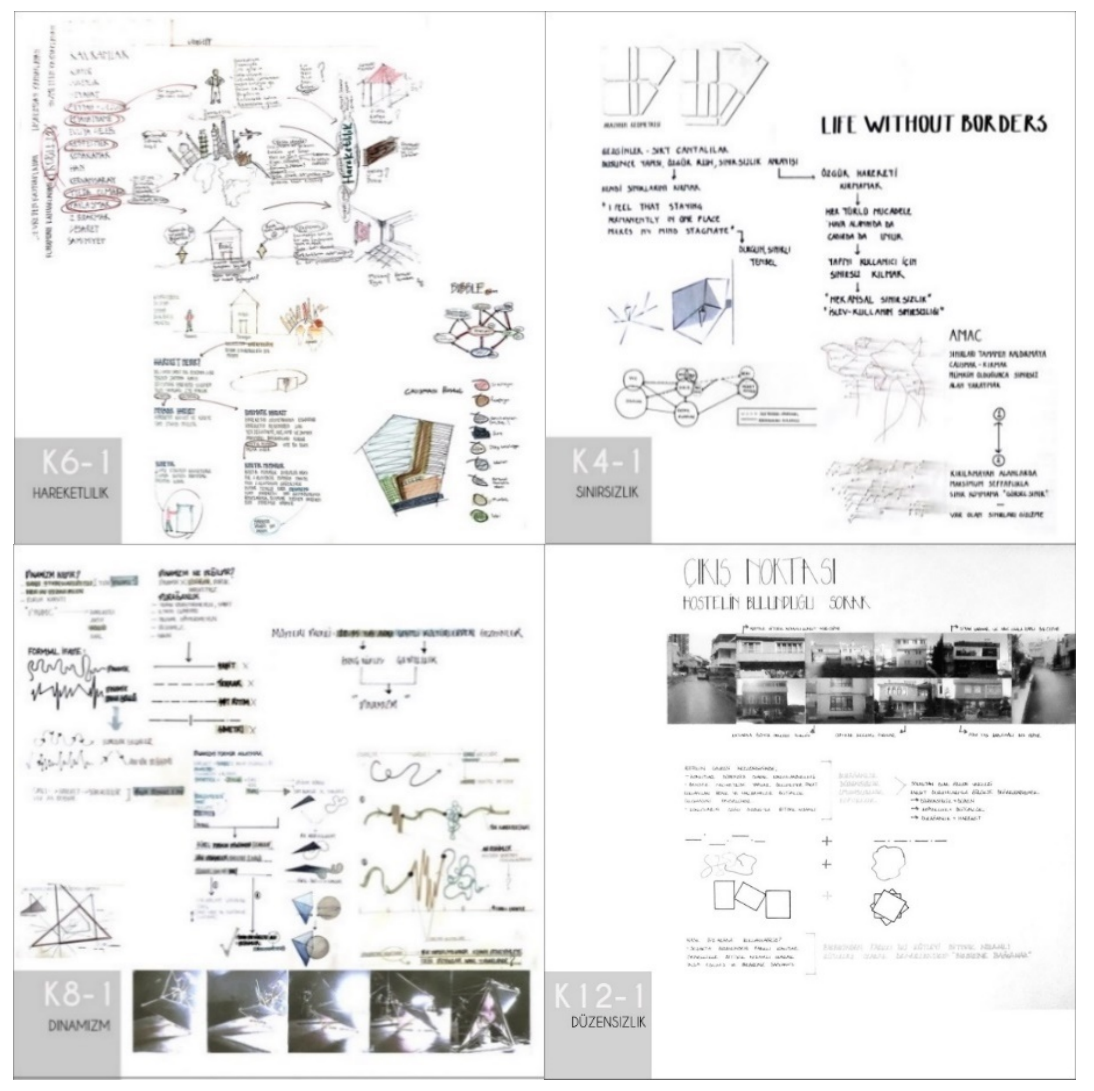

- Students' presentations showed that representation of information varied as verbal or visual, based on cognitive styles. Some participants used verbal expressions, whereas the others externalized information using concept maps, diagrams, symbolic graphics, or just photographs (Figure 11). Regarding the emphasized information, the verbal or visual dominance of these expressions varied. In addition to this, as observed in the study with code K8, the external representations in this phase contributed to the of the ideas in the further stages.

- What distinguishes knowledge from information is that it is interpreted and transformed individually for a specific purpose. External information, combined with the implicit knowledge of designers, builds a new intentional knowledge for design. For this reason, design knowledge refers to processed information about the design issues. In this study, the information that can be accessed from external sources is called the objective aspect of design knowledge, while the acquired or experienced information is called the subjective aspect of design knowledge.

- According to the analysis of projects, the sub-components of objective aspects were identified as the type of space, design program, user profile, architectural limitations, environmental factors, etc. Although, there have been a few, who defined the problem based on environmental factors only, information
Figure 11. The use of concept maps (K6-1), charts (K4-1), symbolic graphics (K8-1), photographs (K121) in verbal and visual representations. 
about the type of space and user profile has gained more importance for the students.

- In this research-based stage, according to students, objective aspects were more important than subjective aspects, because of the desire to be aware of all details about the design problem. However, as sub-components of subjective aspects of the design knowledge, connotations, past experiences, impressions, designer's preferences or tendencies, etc. affected the problem formulation. It was observed that this knowledge depends on life experiences rather than on educational or professional experiences because the participants were secondyear students.

- Students' presentations showed that representation of information varied as verbal or visual, based on cognitive styles. Some participants used verbal expressions, whereas the others externalized information using concept maps, diagrams, symbolic graphics, or just photographs (Figure 11). Regarding the emphasized information, the verbal or visual dominance of these expressions varied. In addition to this, as observed in the study with code K8, the external representations in this phase contributed to the of the ideas in the further stages.

Consequently, along with all these evaluations carried out for the pre-design phase, the components of the problem and knowledge layers were specified as problem definition, problem approach, information source, and information representation which are presented in Figure 12.

Figure 12. Problem and Knowledge Layers of Pre-Design Phase

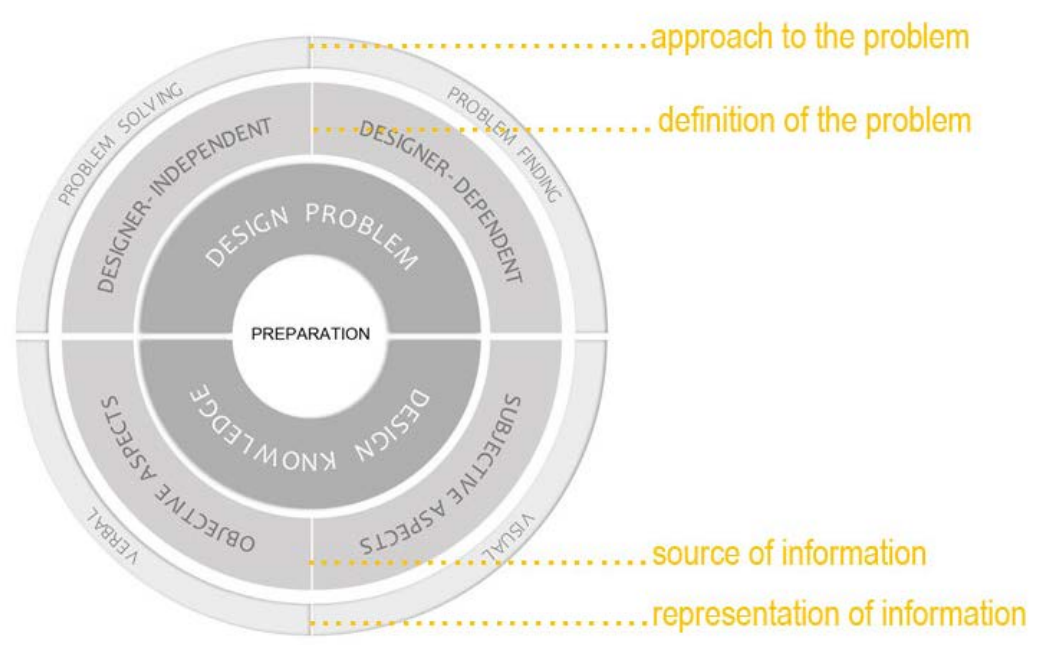

Ideation Phase of The Design Thinking Process

After an intensive contact with the problem defined within the previous phase, the designer aims to find an original idea. For this reason, the transition step referred to as conceptual design in the studio becomes evident at the beginning of the ideation 
phase. During this stage, the designer considers what the design will represent, what it will look like, or how it will be used.

Following the inquiries about the semantic, formal, and functional qualities of space, it is desired to produce a perceptional, emotional, or experiential effect. To find an original idea, the designer needs some triggers, like concepts or images, regarding the aforementioned effects. Verbal or visual representations related to each trigger already have existing expressions in the mind. Therefore, visualization starts through imagination well before any externalization.

The characteristic features of the triggering concepts or images have an effect on the expressions of ideas within the visual thinking process. However, further interpretation of the main qualities is necessary for a unique solution. By means of successive abstraction and concretization, the initial ideas could be developed into conceptual and formal structures, and then spatial solutions.

Based on these explanations, the ideation phase of the design thinking is defined as two stages in which ideas and solutions are generated. In addition to this, the sub-components of the stages are explained according to the following determinations:

- The enlightenment in the pre-design phase establishes an important ground for the design ideation. The initial ideas have become an indicator of the fact that concepts or images, which have a close or distant relationship with the design topic, have interacted with each other consciously or unconsciously. The sources of triggering concepts specified by students have been verbal or visual evocations, past experiences, impressions, and preferences concerning the topic. Concepts that regard the user profile (e.g. freedom, dynamism, etc.) and the distinctive features of space (e.g. socialization, privacy, etc.) have become the primary initiator terms for guiding the design ideas.

- Concepts regarding objective and subjective aspects of design knowledge have been categorized as quality-specifying, object/space-defining, and action-notifying (Table 2). For example, "infinity" for K4 was one of the most important features of the space to be revealed in the end. On the other hand, using "street", K2 designed a hostel similar to another area, while K14 wanted to lead users' behavior with a multifunctional path. 
Table 2. Description and interpretation of concepts QUALITY -SPECIFYING

\begin{tabular}{|c|c|c|}
\hline CONCEPTS & DESIGN IDEA & SPATIAL SOLUTION \\
\hline $\begin{array}{l}\text { K1. } \\
\text { Freedom }\end{array}$ & Freeing the space & $\begin{array}{l}\text { Separating the building } \\
\text { from the ground and } \\
\text { floors from each other. }\end{array}$ \\
\hline $\begin{array}{l}\text { K4. } \\
\text { Infinity }\end{array}$ & $\begin{array}{l}\text { Removing the spatial } \\
\text { definitions and } \\
\text { functional limitations }\end{array}$ & $\begin{array}{l}\text { Reducing the spatial } \\
\text { elements and merging } \\
\text { the functions. }\end{array}$ \\
\hline $\begin{array}{l}\text { K6. } \\
\text { Mobility }\end{array}$ & $\begin{array}{l}\text { Maintaining mobility } \\
\text { in the building }\end{array}$ & $\begin{array}{l}\text { Mobilizing the spatial } \\
\text { surfaces in all directions. }\end{array}$ \\
\hline $\begin{array}{l}\text { K12. } \\
\text { Disorder }\end{array}$ & $\begin{array}{l}\text { Disrupting the row- } \\
\text { housing order. }\end{array}$ & $\begin{array}{l}\text { Differentiating from the } \\
\text { architectural typology } \\
\text { by rotating the building. }\end{array}$ \\
\hline $\begin{array}{l}\text { K8. } \\
\text { Dynamism }\end{array}$ & $\begin{array}{l}\text { Arousing curiosity } \\
\text { with a dynamic } \\
\text { structure. }\end{array}$ & $\begin{array}{l}\text { Using a rising, striking } \\
\text { and dynamic structure } \\
\text { in the building. }\end{array}$ \\
\hline
\end{tabular}

\begin{tabular}{|c|c|c|}
\hline $\begin{array}{l}\text { ACTION-NOTIFYING } \\
\text { CONCEPTS }\end{array}$ & DESIGN IDEA & SPATIAL SOLUTION \\
\hline $\begin{array}{l}\text { K3. } \\
\text { Creating a private space }\end{array}$ & $\begin{array}{l}\text { Generating specialized } \\
\text { modules in common } \\
\text { areas }\end{array}$ & $\begin{array}{l}\text { Forming modules for } \\
\text { individual needs. }\end{array}$ \\
\hline $\begin{array}{l}\text { K13. } \\
\text { Socialization }\end{array}$ & $\begin{array}{l}\text { Bringing together and } \\
\text { separating users and } \\
\text { functions }\end{array}$ & \multirow{2}{*}{$\begin{array}{l}\text { Separating the private } \\
\text { and public spaces with a } \\
\text { multi-function wall. } \\
\text { A functional path to be } \\
\text { encountered within the } \\
\text { building. }\end{array}$} \\
\hline $\begin{array}{l}\text { K14. } \\
\text { Gathering the users }\end{array}$ & $\begin{array}{l}\text { Encountering users on } \\
\text { a promenade }\end{array}$ & \\
\hline
\end{tabular}

\begin{tabular}{|c|c|c|}
\hline $\begin{array}{l}\text { OBJECT / SPACE - } \\
\text { DEFINING CONCEPTS }\end{array}$ & DESIGN IDEA & SPATIAL SOLUTION \\
\hline $\begin{array}{l}\text { K2. } \\
\text { Street }\end{array}$ & $\begin{array}{l}\text { Creating an interior } \\
\text { street }\end{array}$ & $\begin{array}{l}\text { Dividing the building } \\
\text { into separate internal } \\
\text { and external areas } \\
\text { through a circulation. }\end{array}$ \\
\hline $\begin{array}{l}\text { K5. } \\
\text { Puzzle }\end{array}$ & $\begin{array}{l}\text { Different pieces } \\
\text { coming together and } \\
\text { forming the whole }\end{array}$ & $\begin{array}{l}\text { Developing a } \\
\text { construction method } \\
\text { with partition walls. }\end{array}$ \\
\hline $\begin{array}{l}\text { K7. } \\
\text { Backpack }\end{array}$ & $\begin{array}{l}\text { Having a sufficient } \\
\text { amount of the need }\end{array}$ & $\begin{array}{l}\text { Realizing multiple } \\
\text { functions with few } \\
\text { items. }\end{array}$ \\
\hline $\begin{array}{l}\text { K9. } \\
\text { Origami }\end{array}$ & $\begin{array}{l}\text { Reaching the whole } \\
\text { with similar parts }\end{array}$ & $\begin{array}{l}\text { Forming the space by } \\
\text { using folded surfaces. }\end{array}$ \\
\hline $\begin{array}{l}\text { K10. } \\
\text { Stop motion }\end{array}$ & $\begin{array}{l}\text { The contrast between } \\
\text { dynamic and static } \\
\text { elements }\end{array}$ & $\begin{array}{l}\text { Changing the orientation } \\
\text { of repeating similar } \\
\text { items. }\end{array}$ \\
\hline $\begin{array}{l}\text { K11. } \\
\text { Caravan }\end{array}$ & $\begin{array}{l}\text { Multiple functions in a } \\
\text { narrow space }\end{array}$ & $\begin{array}{l}\text { Using compact solutions } \\
\text { as in a caravan. }\end{array}$ \\
\hline $\begin{array}{l}\text { K15. } \\
\text { Inn }\end{array}$ & $\begin{array}{l}\text { Similar solutions as in } \\
\text { a traditional example }\end{array}$ & $\begin{array}{l}\text { Locating the } \\
\text { accommodation units } \\
\text { around an inner court. }\end{array}$ \\
\hline
\end{tabular}

- It has been observed that the concepts have been dealt with in two ways. Some students have used them as a tool (e.g. caravan, street, module), while, others have used them for a purpose (e.g. freedom, infinity, dynamism). For example, using 
sleeping units for private solutions in K11, the concept of "modules" has become a tool for design solutions. In contrast, the concept of "freedom" has shown the design purpose of K1, rather than a design solution.

- It has also been determined that the design idea is associated with at least one of the semantic, formal and functional parameters of the space. Each study came to an end with a spatial form, but the relationship with the semantic and functional parameters varied. In the study with code $\mathrm{K} 4$ for instance, the concept of "infinity" was interpreted as "the spatial and functional infinity", so it was associated with all those parameters. On the other hand, K13 aimed to isolate private spaces through a volumetric path, and only the functional parameter has been taken into consideration.

- It has been observed that there are several relationships between concepts and images depending on semantic, formal, or functional transitions. The formal transition has been referred to as an analogical exposition, the semantic transition as a metaphorical exposition, and the functional transition as a usage exposition. In the case of concepts such as freedom, infinity, and mobility, the typical feature of concepts has been transferred to space semantically, which is a metaphorical exposition. For example, the concept of "freedom" has been defined through "the situation without any restrictive connection" in $\mathrm{K} 1$, and the building as an unbound person or thing was raised by separating from the ground (Figure 13). In different circumstances, an analogical exposition has been used through concepts that describe a concrete object/space such as "caravan, street, or inn". In such concepts, there was a formal or functional similarity between the source object and the final space. In the example in Figure 13, the inner plan of the inn has transferred in the pension with an atrium. In other studies, triggering ideas that imply an act such as comparison, socialization, or isolating the private space, has provided a new usage. 
Figure 13. Examples of semantic transitions (K1), and formal transitions (K15).

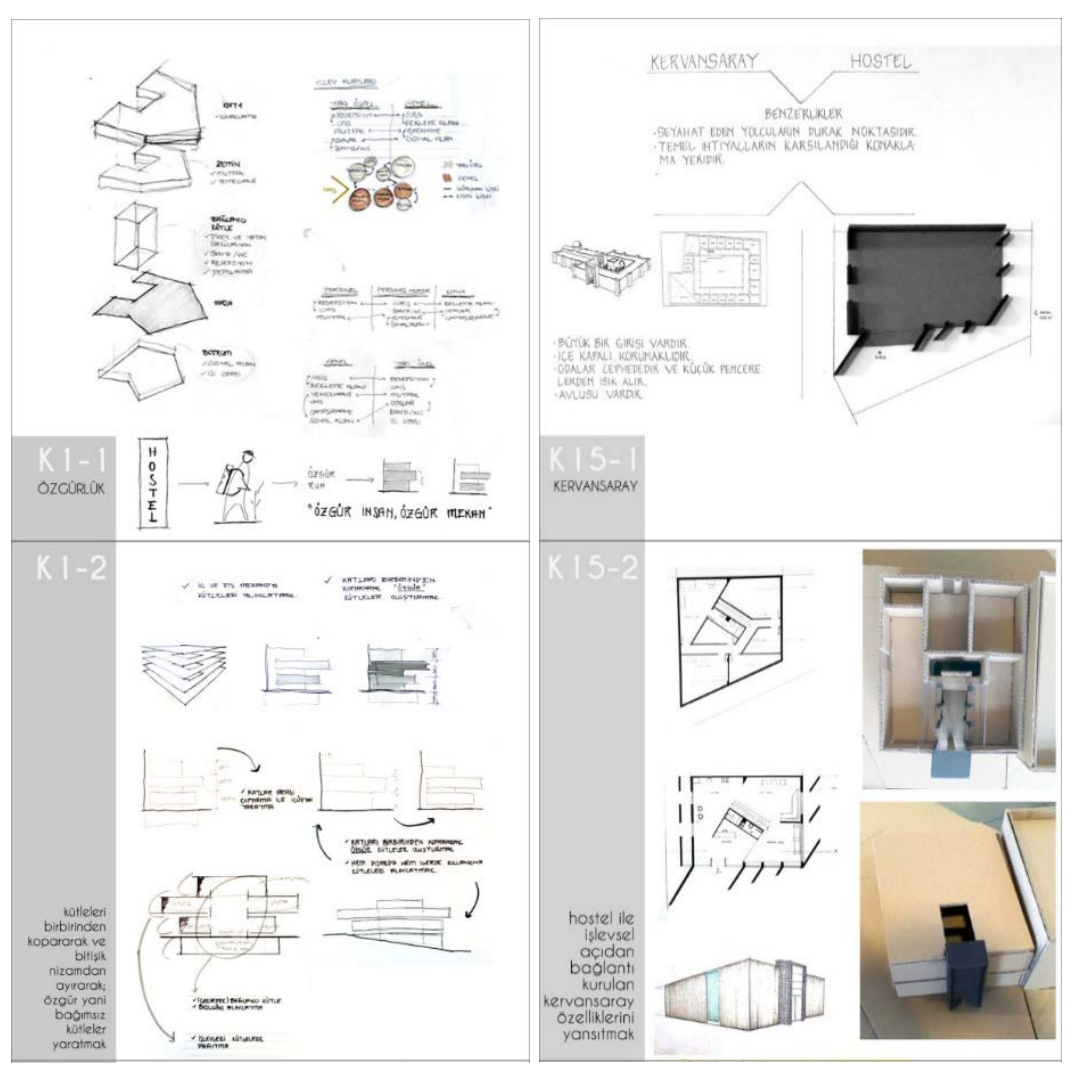

- After the conceptual stage, it became necessary to define characteristic features of concepts and images in order to reflect them to the spatial aspects. In the example of $\mathrm{K} 6$ "mobility" was represented visually by moving the spatial surfaces like walls, grounds, or ceilings toward different directions in an immobile space. In the other project with code K11, a compact solution similar to the caravan was put forward in order to implement multiple functions in the limited space. In other words, the functional solutions gained more importance than the formal aspects of space. 
- It was observed within the studies carried out that some students processed concrete concepts like street, origami, puzzle, etc. whereas the others preferred abstract concepts like infinity, mobility, dynamism, etc. in the idea generation stage. Formal features of the concrete conception enabled the use of it as a source. However, students who preferred abstract concepts had to look for other formal sources. Depending on this, two types of form-giving approaches, space-dependent, and space-independent have been detected. The observations showed that space-dependent solutions relied on an existing architectural space or environment, whereas spaceindependent solutions relied on other existing images or archetypes, which were generated by the designer. For example, conceptual sketches and draft models were made for embodying "dynamism". These abstract trials have been gradually embodied and turned into the space through functional parameters in K8. However, in the other project in which the concept of "socialization" was used, the formal aspects of the existing architectural space were utilized because there was not any associational form of the concept (Figure 14). Besides, in the study with code K2, the existing building was divided into two separate blocks through a walkway similar to a "street".
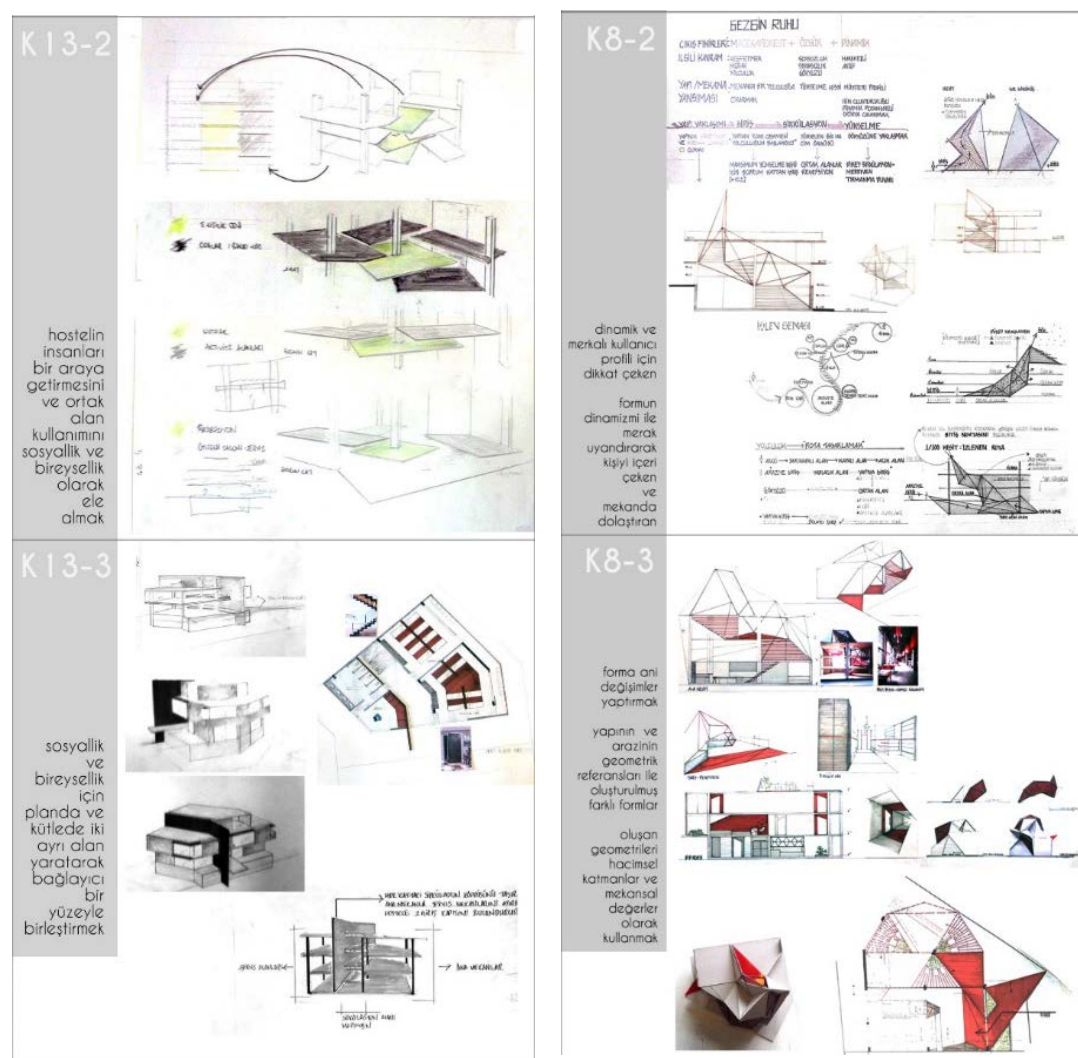

- In space-dependent designs, the geometric properties of existing architectural space were mostly preserved as in the

Figure 14. Examples of modification (K13) and adaptation (K8). 
K13. However, in space-independent designs, different formation technics have been detected. Regarding this, using visual aspects of an image was defined as a transformation, using geometric aspects of the existing building was defined as a modification, and using another archetype was defined as an adaptation (Figure 14).

Based on the determinations above, the ideation phase has been defined within two stages, as conceptualization (idea generation) and spatialization (solution generation). The sub-components of the stages and the ideation approaches are shown in Figure 15.

Figure 15. Layers and components of Ideation Phase
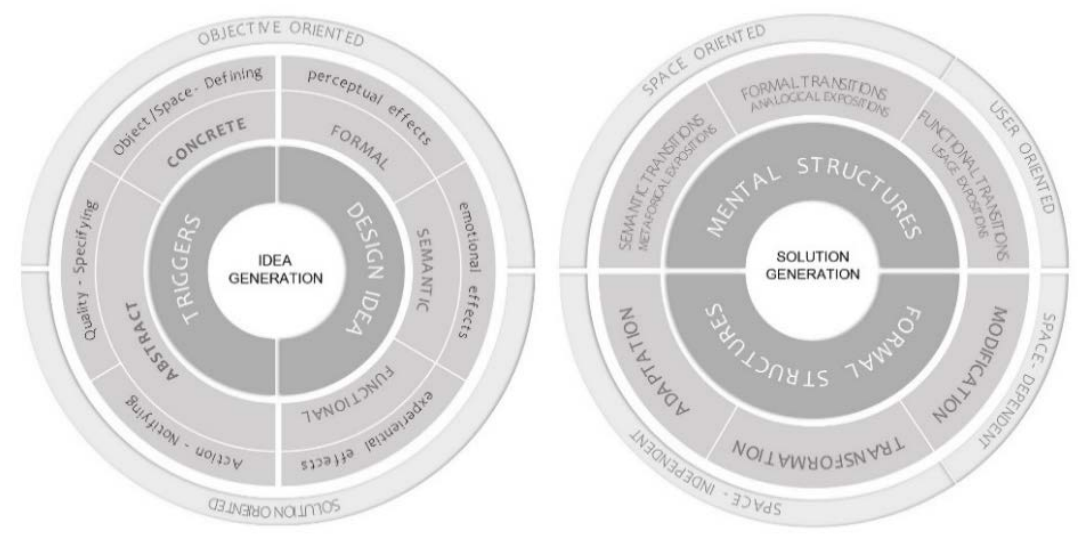

Based on these evaluations, two of the diagrams, formed in the pre-design phase and the ideation phase, have been associated with each other and expressed by a model of design thinking. The details of the model and recommendations for future studies are stated in the conclusion section.

\section{CONCLUSIONS AND RECOMMENDATIONS}

Based on the study, the pre-design phase and the ideation phase have been determined as two main stages of the design thinking process. The components of the pre-design phase were defined as design problem and design knowledge. On the other hand, the ideation phase has been divided into two sub-processes that include the generation of ideas and solutions.

In the conceptualization stage, the layers of triggering concepts or images and the main idea have been analyzed. In the following spatialization stage, the layers of mental and formal structures have been discussed. Individual differences specified through the qualitative analysis of the students' works have constituted the subcomponents of each layer. Ultimately, with this content of data, a model has been proposed (Figure 16).

According to the model, the definition of the design problem varies depending on how the designer handles it. The designer's approach to the problem shows the relationship between the two main styles, problem-solving and problem-finding. On the other hand, design knowledge as one of the most important 
factors of design ideation also varies according to the problem definition. The designer processes his/her past experiences, educational or professional acquisitions, and his/her subjective tendencies with essential information about design the problem. In other words, the design knowledge and the design problem interactively initiate the design process. Therefore, the predesign phase of the model is considered the first step for originality in the design process.

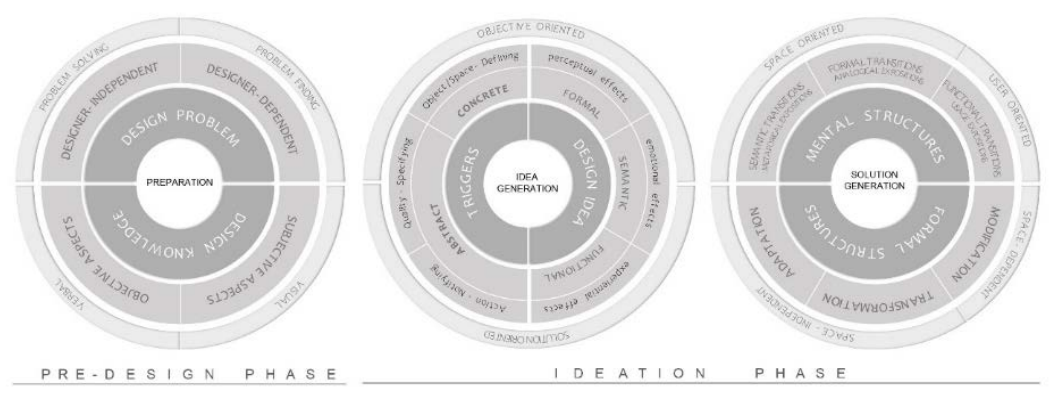

At the beginning of the ideation phase, the designer searches a good reason or a design purpose through the information acquired. This is the most important step of the model, especially for educational practice. Because the internal process of design thinking starts to externalize during this conceptualization stage. For the externalization of these implicit operations, the designer often needs some initiators, such as images or concepts related to the design problem. The triggering concepts or images relate to at least one of the semantic, formal or functional parameters of the design. These concepts, which can be concrete or abstract, begin to emerge both mentally and physically through imagination and representation. Therefore, the unique purpose of the designer and the semantic, formal or functional ways to achieve it are determined at this conceptualization stage.

Form-giving to an idea is another important stage that varies according to the type of design discipline. In design disciplines related to the living space like interior design, some architectural or environmental limitations affect the design. These limitations should be considered, but there are also some opportunities to interpret them uniquely with the help of concepts in the previous stage. In addition to modifying the architectural form, generating an archetype or transforming the visual qualities of the design concept can be used for the spatialization method.

As a result, the model summarizes all the methods observed in this study to show different options for users. Additionally, this model has also been designed to be used as an analysis tool for other studies. Because of this, each stage has been represented with a circle and each circle has been divided into layers and
Figure 16. Infographic Model of Design Thinking Process 
sub-components in the graphic expression of the model. In this way, an information chart has been generated, that each student can be coded in different colors and her/his design process can be pinned on the model. In the example of Figure 17, 5 students have been integrated into the model according to their similarity in conceptual design and the divergent processes have been evaluated.

Figure 17. Using the Infographic Model of Design Thinking Process as an analysis map.

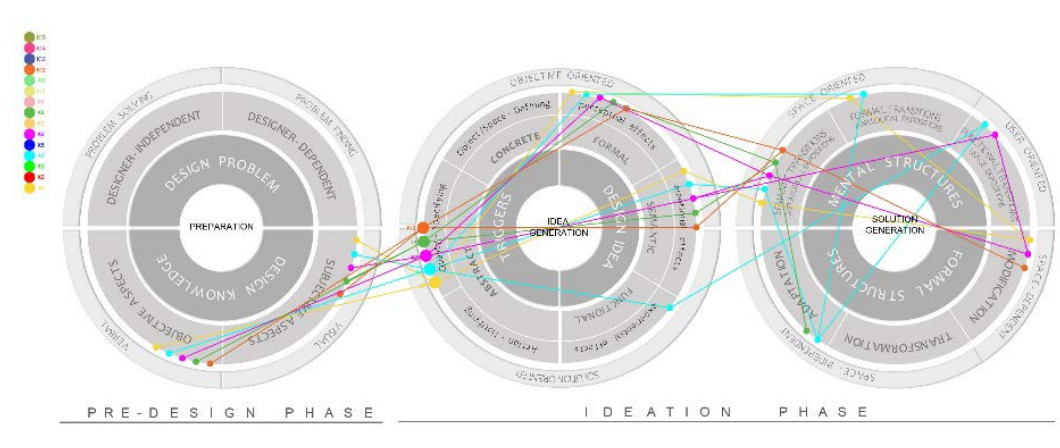

For example, K4 differs among these students as s/he used all the possibilities of semantic, formal and functional parameters during the ideation phase. Besides this, there isn't any qualityspecifying concept, which used the transformation in the spatialization stage. Regarding this, the model allows further analyses of any stage or the whole process, and it can be expanded with different contains.

The primary purpose of the model is to give information about the process, components, and different approaches, whereas the secondary aim is to provide a template for monitoring the data analysis. It has the potential to demonstrate both information content and data analysis simultaneously. For this reason, the model is referred to as the infographic model of design thinking, The model does not suggest a specific design method but documents the previously employed methods in the studio. With this regard, it should be considered as a content map that represents potential ways of thinking. These ways crossed or separated according to designers' approaches at significant junction points have been recognized as essential moments in design, especially in terms of diversity and originality.

In conclusion, this study intends to observe the creativity process rather than measuring creativity in design studios. With the proposed model, it is aimed to offer a two-way contribution to design education. The first one is to discover the important moments, which have the potential to guide the design process, thereby leading the design students to an alternative way of thinking. The second contribution of the model is to introduce both an ideational and a graphical template for further analyses or evaluations to be carried out in design studios. 


\section{ACKNOWLEDGMENTS}

I would like to thank both design students who participated in the study and my instructors and colleagues for their valuable contributions to this research.

This paper is based on the doctor of fine arts thesis entitled "Cognitive Competence and Creative Process in Design Studio Education"' that was conducted within Institute of Fine Arts at Hacettepe University in 2018.

\section{REFERENCE}

Akın, Ö. (1978). "How Do Architects Design?", pp. 65-98 in Artificial Intelligence and Pattern recognition CAD, edited by G. Latombe, New York: North Holland.

Andreasen, N. (2011). Yaratıcı Beyin Dehanın Nörobilimi, trans. by K. Güney, Ankara:Arkadaş Yayınevi.

Benami, 0. (2002). Cognitive approach to creative conceptual design (Ph.D Thesis). Los Angeles: University of Southern California.

Cross, N. (2001). "Design cognition: results from protocol and other empirical studies of design activity", pp.79-103 in Design knowing and learning: cognition in design education, edited by C. Eastman, W. Newstatter, and M. McCracken. Oxford, UK: Elsevier,

Demirbaş, Ö. 0. (2001). The relation of learning styles and performance scores of the students in interior architecture education (Ph.D Thesis). Ankara: Bilkent Üniversitesi.

Demirbaş, Ö. O., Demirkan H. (2003). "Focus on architectural design process through learning styles", Design Studies, 24: 437-356

Fakhra, A. J. (2012). Conceptual Model of Design Creativity: Fostering Creative Cognition in Architecture and Design Pedagogy (Ph.D Thesis). Chicago: Institute of Design.

Finke, R. A., Ward, T. B., Smith, S. M. (1992). Creative cognition: Theory, research, and applications. Cambridge: MIT Press.

French, M. J. (1985). Conceptual design for engineers. London, UK: The Design Council/Springer.

Getzels, J. W., Jackson, P. W. (1962). Creativity and intelligence: Explorations with gifted students. New York: Wiley.

Goldschmidt, G. (1994). "On visual design thinking: the vis kids of architecture”, Design Studies, 15(2): 158-174.

Guilford, J. P. (1968). Intelligence, creativity, and their educational implications. San Diego: RR Knapp.

Kahvecioğlu, N. P. (2001). Mimari Tasarım Eğitiminde Bilgi ve Yaratıcılık Etkileşimi (Ph.D Thesis). İstanbul: ITU.

Kwan, T., Yunyan, J. (2005). "Students' learning styles and their correlation with performance in architectural design studio", Design Studies, 26(1) : 19-34. 
Lawson, B. (2005). How Designers Think: The Design Process Demystified, Oxford: Architectural Press.

Lowenfeld, V.(1947). Creative and Mental Growth, New York: Macmillan.

Martinsen L. Ø., Kaufman G., and Furnham A. (2011). "Cognitive Style and Creativity", pp.214-221 in Encyclopedia of Creativity, edited by M. A. Runco and S. R. Pritzker. Academic Press.

Mednick, S. A. (1962). "The Associative Basis of the Creative Process", Psychologyical Review, 63(3): 220-232.

Mumford, M. D. (2003). "Where have we been, where are we going? Taking stock in creativity research", Creativity Research Journal, 15: 107-120.

Newell, A., Herbert A.S. (1972). Human problem solving. NJ: Prentice-Hall.

Ochsner, J. K. (2000). "Behind the Mask: A Psychoanalytic Perspective on Interaction in the Design Studio", Journal of Architectural Education, 53(4): 194-206.

Oxman, R. (1997). "Design by re-representation: a model of visual reasoning in design", Design Studies, 18: 329-347.

Oxman, R. (2004). "Think-maps: teaching design thinking in design education", Design Studies, 25(1): 63-91.

Rhodes, M. (1961). "An analysis of creativity", Phi Delta Kappan, 42: 305-310.

Roberts, A. (2006), "Cognitive Styles and Sudent Progression in Architectural Design Education", Design Studies, 27: 168181.

Rouquette, M. L. (1992). Yaratıcılık, trans. by Işın Gürbüz, İstanbul: İletişim Yayınları.

Runco, M. A. (2007). "Cognition and Creativity", pp.1-38 in Creativity: Theories and Themes: Research, Development, and Practice, edited by M. A. Runco, Elsevier.

Runco, M. A., Chand, I. (1995). "Cognition and creativity", Educational Psychology Review, 7: 243-267.

Salama, A. M. A.; Wilkinson, N. (2007). Design studio pedagogy: Horizons for the future. Gateshead, U.K.: Urban International Press.

Schön, D. A. (1985). The Design Studio, London, UK: RIBA Publication LTD.

Smith, S. M., Thomas B. W., and Ronald A. F. (1995). The creative cognition approach. MIT Press.

Torrance, E. P. (1972). "Predictive validity of the Torrance tests of creative thinking", The Journal of Creative Behavior, 6(4): 236-262.

Türkyılmaz, Ç. C.; Polatoğlu Ç. (2012). "Erken Tasarım Evresinde Bilginin Dönüşümü Üzerine Bir Model Önerisi; Yıldız Teknik Üniversitesi Mimari Tasarım 3 Stüdyosunda Bir Deneme", Megaron, 7(2): 103-115. 
Uluoğlu, B. (1988). "Tasarım Stüdyosuna Bir Bakış", Planlama, $88(2): 21-25$.

Wallas, G. (1926). The art of thought. London: Jonathan Cape.

Ward T. B. (2007). "Creative cognition as a window on creativity", Methods, 42: 28-37.

Weisberg, R. (1986). Creativity: Genius and other myths, $A$ series of books in psychology. US: W H Freeman / Times Books / Henry Holt \& Co.

Zeisel, J. (2006). Inquiry by design: environment/ behavior/ neuroscience in architecture, interiors, landscape, and planning (Rev. ed.). New York: W.W. Norton \& Company.

\section{Resume}

Pelin Koçkan Özyıldız, received her B.Arch (2009), MSc. (2012) and $\mathrm{PhD}$ (2018) from Department of Interior Architecture \& Environmental Design, Hacettepe University. She currently working as a Research Assistant at Hacettepe University.

Pelin Ylldız, received her B.Arch (1994), MSc. (1997) and PhD (2001) from Department of Interior Architecture \& Environmental Design, Hacettepe University. She currently working as a Professor at Hacettepe University. 